\title{
仏国寺外部空間の比例体系分析
}

\section{A Study on the Proportion System of the Outdoor Space in Bulguk-sa Temple}

李 鉉澤* 李 姃*

Hyun-Taek LEE, Jeong LEE

\begin{abstract}
摘要 : 本考は，嘾国の伝統空間における空間の尺度概念を，歴史的な文化財である輤国庵州の仏国寺 の外部空間を対象に分析することによって，祖先たちの美の原理による空間の処理技法を把握するこ とを目的としたものである。その方法としては，仏国寺の平面図を用いてデザイン原理の1つである 比例体系の枠組みで分析した。その結果, 1.382 矩形の比例尺度が定型的かつ体系的な形態として導 き出された。

また，このような1.382矩形の比例尺度は同時代に建てられた，慶州所在の千軍里寺址の外部空間 でも確認することができた。
\end{abstract}

1.はじめに

われわれが日常的に接している桧画や音楽 が, その全体構成に関する各部の適正な調和 を必要とするように, 他の芸術的な構造にも その各部の組合せにふさわしい比例と均衡が 必要である。特に外部空間を主な対象とする 造園計画においては，周辺環境之細部造形物 の間の適切な配置を考虑し，空間を調整する 必要がある。いわゆる，美学的な秩序原理が それである。

比例とは，部分と全体，部分と部分との大 きさ (Scale) の関係を意味し, 均斉（Symmetry) やリズム (Rhythm) とともに, 造 形芸術を支える 3 大構成要甞であり, 空間に おける数量関係に関する美的形式原理の 1 つ であある1。

比例は, 調和の根本となる内的秩序として, 様々な図式によって説明されるが，その中で す建築計画, 特に古代の建築物に多く応用さ れて来た。

韓国の伝統空間の比例に関する今までの研 究は，主に伝統的な寺刹空間を中心に行なわ れており，その内容は内部空間や造形物に関 するるのと外部空間に関するものに二分され る。

先ず，内部空間や造形物に関する研究とし ては, 本光老 ${ }^{2}$ が新羅時代の石塔や栄州浮石 寺の無量寿殿の平面, 立面を分析し, 正方形 及び、系列の長方形， $3: 5$ 比を提示してい る ( $3: 5=1.666$ 。これは, $1.618 の$ 実用値)。 また，米田美代治 ${ }^{3}$ は石窟庵の造営分析か ら得られた一定の単位モジュールを幾何学的 な体系として説明しており，姜友邦“は石窟 庆の造営に 22 矩形が利用されたことを指摘 している。
その反面，文明大 ${ }^{(3)}$ の場合は石窟庵を 1.382 矩形を用いて米田や姜友邦とは異なる結果を 出している。

また，物理学者である南天祐 ${ }^{5)}$ は，自分が 測った石窟庵の実測図之米田や姜友邦が用い た石窟庵の復元図を比較し，現在の石窟庵の 平面構成が日本人によって復元，修理される 際に，工事の便宜を図るために一部が操作さ れた平面構成になっていると主張している。

次に外部空間の比例研究としては，宋旼 求 ${ }^{6}$ は統一新羅時代に造営された四天王寺, 感恩寺, 千軍里寺, 仏国寺等の黄金分割の概 略的な適用を指摘している。

また，俞福模”はは写真測量法を用いて仏国 寺を分析し，大雄殿，紫霞門，釈迦塔，多宝 塔などの位置が石塔を中心に，等距離上の比 例を成しており，釈迦，多宝の両塔は長方形 の造形比を基礎とした比例関係にあることを 指摘している。

以上の研究内容を見ると，塔や仏像の上う な造形物そのものの比例に関するすのが多く， 一部の外部空間を扱ったものも可視的な輪郭 を扱っているのみで, 全体外部空間の中での 重要構成要素間の位置選定や相互関連性によっ て現われる空間比例に関する研究はあまり見 あたらない。従って，本考は仏教を国家統治 理念の中枢に置いた，いわゆる国家仏教が盛 んであり, 国力, 政治力, 文化的水準などが 頂点に達していた統一新羅時代に造営された 慶州所在の仏国寺を対象に，その伽藍の配置 上に現われる造営特性を, 比例体系を中心に 考察することによって，そこに内在されてい る伝統的な美の原理による空間処理技法の把 握を目的としたものである。

\section{2. 研究の方法}

調查は文献調查之現地調査に分けて実施さ れた。

参考文献としては, 創建当時の歴史的背景 を理解する為の「三国遗事 ${ }^{8)}$ ，「仏国寺古今 創記」き)などの古い記録をはじめ,「華厳経」 「法華経」などの経典 ${ }^{10)}$ ，米田美代治の「朝鮮 上代建築に関する研究」3), 韓国文化財管理 局の「仏国寺復元報告晴」"1)などを主に参考 にした。また，外部空間に関する理論書及び 外部空間の分析や比例理論の関連文献, 测量 分析に関する書籍も参考にした。現地踏查と 並行して図面の分析や実測む行なった。分析 に用いた配置現況図は, 韓国文化財管理局の 「仏国寺発掘復元報告曺(1987)」を使用し， 図面の誤差を確認する為に部分的な補完実測 を行なった。

分析の内容は，大雄殿を中心とする一角の 図面を対象に，正方形を基本図形として幾何 学的な面積解釈と全体的な形態内での重要要 素の位置決定が容易なハムビッジ（Hambidge $)^{2)}$ の長方形分割法に従って行なった。 具体的には，ハムビッジの 6 種類のギリシャ 比例体系（正方形, $\sqrt{ } 2, \sqrt{3}, \sqrt{4}, \sqrt{5}$, $\phi)$ の中で, 黄金比例の内在的な要素であり, 黄金矩形の作四から自動的に導き出される1. 382矩形による空間構造分析を行なった。

比較する事例としては, 仏国寺と対象地の 位置, 築造時期が同一である慶州所在の千軍 里寺址の空間構造分析を行なった。

\section{3. 分析及ひ考察}

(1) 1.382矩形による空間構造の分析

(i )1.382矩形之主要造形物との関係分析

先ず，仏国寺の中心一郭を限定している回

•韓國慶北大學校農科大學造景學科 
廊の外柱を基準線とし，北側の外柱 $(\mathrm{AD})$ を 短辺, 南側の外柱 $(\mathrm{AB})$ を長辺とする長方形 $\mathrm{ABCD}$ を求めた。この結果, 短辺：長辺の 比は，169尺：234尺う1：1.384として1.382 矩形を成していることがわかった（1唐尺= $0.297 \mathrm{~m}$ )。

1.382矩形之は，黄金矩形の左右の極を通 して対角線を下ろした時に生じる側面の 5 矩形を除外した，残りの矩形をいう。この矩 形の各々の頂点から対角線を下ろし，それら の結ばれるところに中点 $(0)$ を設定した。

この中点 $(0)$ を中心，仏国寺の殿閣の中 で造成年代が最む早い無説殿9)の中心柱( $(\mathrm{ab})$ の中点 $(\mathrm{k})$ と，創建初期からの現存物である 石燈 (c), 多宝塔 (e), 釈迦塔(d)の中心点を 通る各々の円を求めると，これらの相互関係 は等間隔の同心円を表わす。これは，無説殿， 石燈，多宝塔，釈迦塔など，仏国寺の主要殿 閣や造形物の位置選定と，空間内で統一され た体系として構成されている1.382矩形との 間の密接な関連性を示唆するものであると思 われる。図-2は，回廊の外柱を基準線とし た1.382矩形と主要造形物との関係を分析し たものである。

（ii）回廊の外柱を基点とした空間構造の分 析

図-3は，仏国寺の重要部の境界を成して いる回廊の外側の柱 $(\mathrm{AD})$ を基点として，(A D)を 1 辺とする方形の対角線の長さを長辺 (AE)(DF)とする矩形を表わしたもので，そ の短辺と長辺は $1 ： 1.382$ の矩形を成してい る。

(1)全体平面は多宝塔の北側の階段線上を通る

線分 $(\mathrm{BC})$ を基点として，無説殿，大雄殿

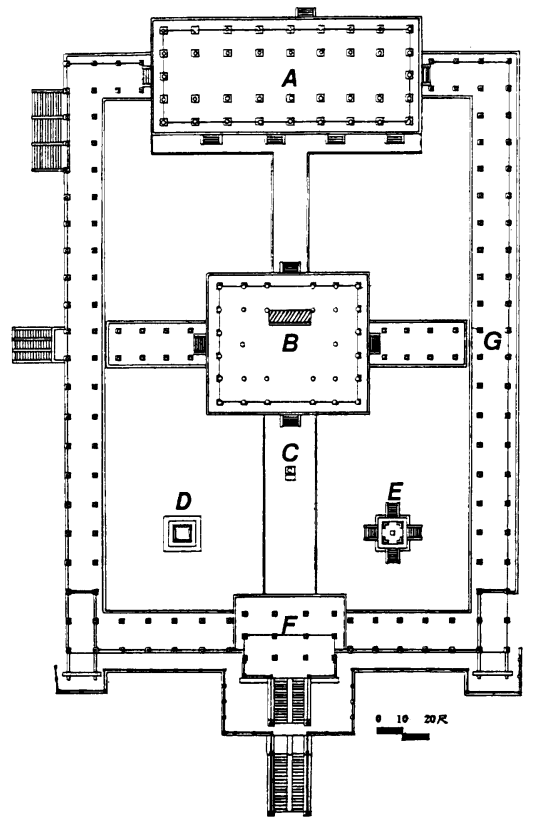

図- 1 仏国寺平面配蛋図

A. 無説殿 B.大雄殿 C. 石燈 D. 釈迦塔 E.多宝塔 F.紫霞門 G.回廊
を中心とする上部の正方形空間( $\mathrm{ABCD}$ ) と，塔と紫霞門を中心とする下部の0.382 矩形 (2つの正方形之 $\phi$ 矩形) (BEFC)に 分けられる。

(2)この上部の正方形空間 $(A B C D)$ は, 更に 大雄殿を中心とする $\phi$ 矩形 $(\mathrm{GBCH})$ と無 説殿を中心とする0.382矩形(AGHD)の 2 つに分割される。

即ち, 無説殿を中心とする 0.382 矩形 $(\mathrm{A}$ GHD)と下部の紫霞門を中心とする 0.382 矩形 $(\mathrm{BEFC})$ は，大雄殿を中心とする中央 の $\phi$ 矩形 $(\mathrm{GBCH})$ を間に上下対称の関係 にある。

(3)大雄殿を中心とする $\phi$ 矩形 $(\mathrm{GBCH})$ は, 大雄殿の左右の翼回廊（東長廊，西長廊） の最初の柱を通る線分(IJ)，(LK)を基点 に，石燈を含む大雄殿中心の縦形の 1.382 矩形(IJKL)とその両側の $2 つ の \sqrt{ } 5$ 矩形 (GBJI) (LKCH)に分割される。大雄殿中 心の縦形の1.382矩形(IJKL)は, 大雄殿の 仏像座台を通過する線分(MP) と大雄殿入 口の最初の階段線(NO)を基点に, 中央の $\phi$ 矩形(MNOP) と上下部の $\sqrt{5}$ 矩形 (IMP L,NJKO)に分割される。特に，仏像座台 上を通る線分 $(\mathrm{MP})$ は $\phi$ 矩形の分割線と一 致している。

これは仏寺で最も重要な仏像座台の位置 の持つ意味上の美的概念之, あらゆる美的 比例の中で最も完全な比例とされる $\phi$ 矩形 との一致を表わすむので，仏国寺の造営で 見られる数理学的な空間尺度からも確認す ることができる。このような大雄殿の仏像 座台の位置と $\phi$ 矩形の一致は, 宋旼求の浮 石寺の無量寿殿の平面比例分析でむ見るこ
とができる。

(4)多宝, 釈迦の両塔之紫酸門を中心とする 0.382矩形(BEFC)は，紫霞門全面の柱の横 幅 $(b c)$ を短辺とし，紫霞門中心空間の $\phi$ 矩 形(abcd)之左右の両塔が安置された $2 つ$ の正方形空間(BEba,dcFC)に分割され，

それぞれ伽藍の人口部分と側面部分を形成 している。

紫霞門中心の $\phi$ 矩形 (abcd)は，更に紫 霞門全面の柱 $(\mathrm{YZ})$ を基点に，上部の紫霞 門前庭部分である正方形空間 (aYZd)と下 部の紫霞門建物部分の $\phi$ 矩形 $(Y b c Z)$ に分 割される。なお，この空間の基点となる紫 霞門の前面の柱(YZ)は回廊の内側の境界 部分であある。

紫霞門を中心に，左に形成される积迦塔 を中心とする正方形空間(BEba)は，正方 形の 1 辺を長辺とする $\phi$ 矩形 (eEbf)を下 部にして, 上部の小さい $\phi$ 矩形 (Behg) と 塔の内部基檀部の位置を決定する正方形空 間(ghfa)に分割される。多宝塔が安置さ れた紫霞門の右の正方形空間 $(\mathrm{bcFC})$ でも 同じ形態の空間分割が行われており，釉边， 多宝塔の内部基楆部の位冝が $\phi$ 矩形之正方 形の分割線となる。

(5)無説殿を中心之する0.382矩形(AGHD)は, 無説殿の中心部を $\phi$ 矩形 (ijkl)に，左右の 回廊空間を正方形 $(A G j i, 1 \mathrm{kHD})$ に分割す る。そして, 無説殿中心部の $\phi$ 矩形 (ijkl) は，更に無説殿の内部前面の柱線 $(\mathrm{mn})$ を 基点として，無説殿の前庭空間を正方形 $(m j k n)$, 建物の一部を $\phi$ 矩形 $(\mathrm{imnl})$ に 分割する。

以上のように，1.382矩形を利用した仏国

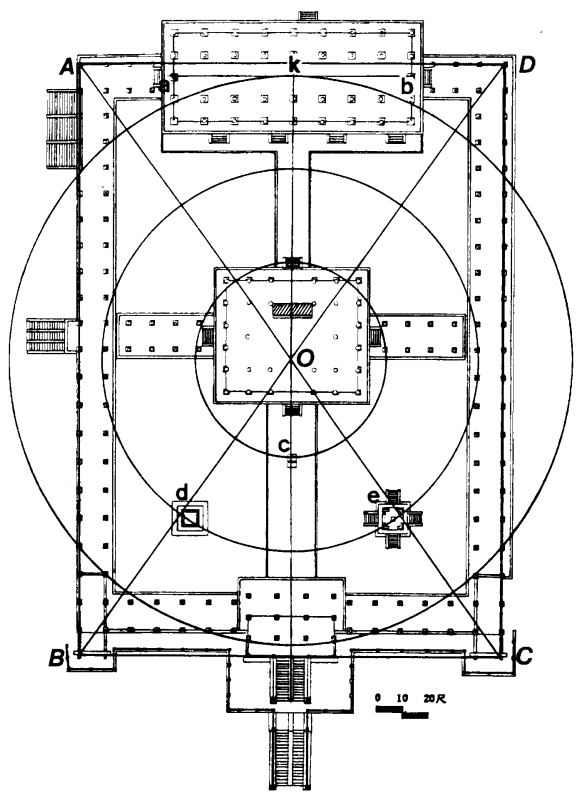

図一－1.382矩形と主要造形物との関侻 分析

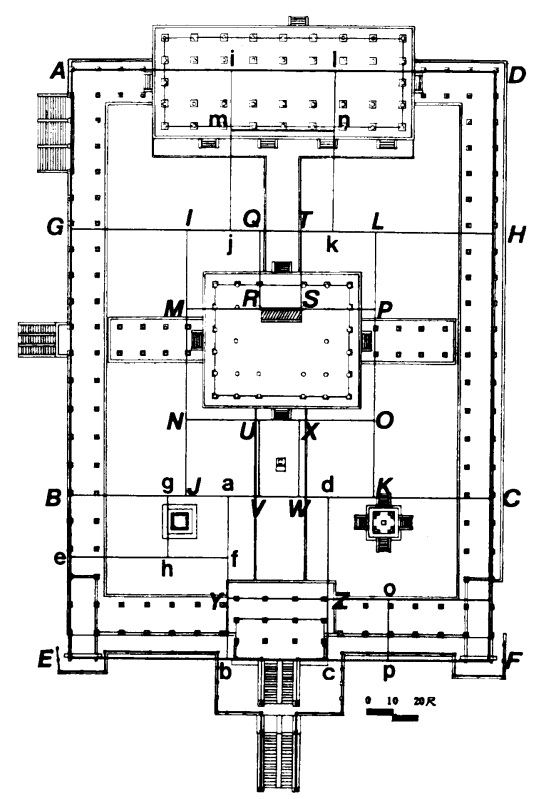

図ー3 1.382矩形による空間搆造の分析 


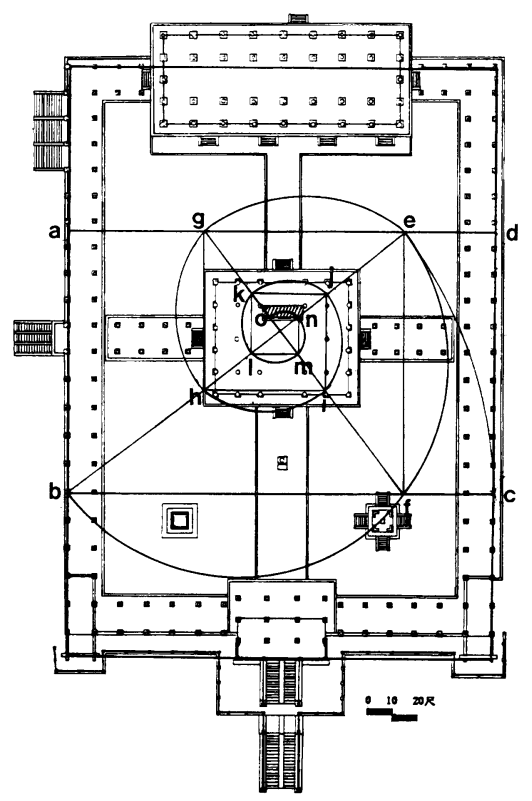

図-4 対数蝶線 $(\sqrt{ } \phi)$ を用いた仏像 座台の配置分析

寺の空間構造を分析した結果, 紫霞門前面の 柱線(YZ), 大雄殿前面の階段線(NO), 仏像 座台の位置 (MP), 無説殿前面の柱線 $(\mathrm{mn})$ などは，全て $\phi$ 矩形と正方形空間を分割する 分割線としての役割を果たしており，これら が成立させる空間を基に，他の空間が互いに 連帯的な関連を結んでいる。

なお，紫霞門中心空間(abcd)，石燈付近 の空間(UVWX)，大雄殿の仏像座台から入 口階段までの空間(MNOP)，仏像座台の後 面空間(QRST), 無説殿中心空間(ijkl)など は, 全て $\phi$ 矩形で構成され，平面上の 1 つの 垂直軸を形成しており，全体のそれぞれの空 間はこの軸を中心に上下，左右に対称的に配 置されている。

このような空間構成の対称技法は，空間に 強い安定感を与え, 寺刹空間を持つべき荘厳 かつ厳肃な宗教的雾囲気を醇し出している。

対称による空間構成技法は，ギリシャ以来 の美的原理として, 造園, 建築などの分野で よく使われており, 古代から象徽性を必要之 する重要建築や古典的な建築に数多く利用さ れ，特に宗教的な建築における権威的で，形 式的な空間の表現技法として応用されてきた。

このような 1.382 比例は，ハムビッジのパ ルテノン神殿(1) の分析結果 ( $\phi$ 矩形より導か れた1.328矩形と「5矩形で全体の均衡を保っ

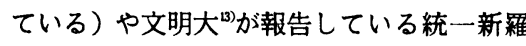
時代の造形物の分析から導かれた 1.33 比例と も類似している。

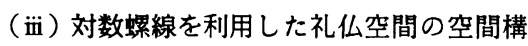
造分析

図-4は1.382矩形 (図-3) の中で, 大雄 殿一帯の礼仏空間である $\phi$ 矩形 (abcd)を対

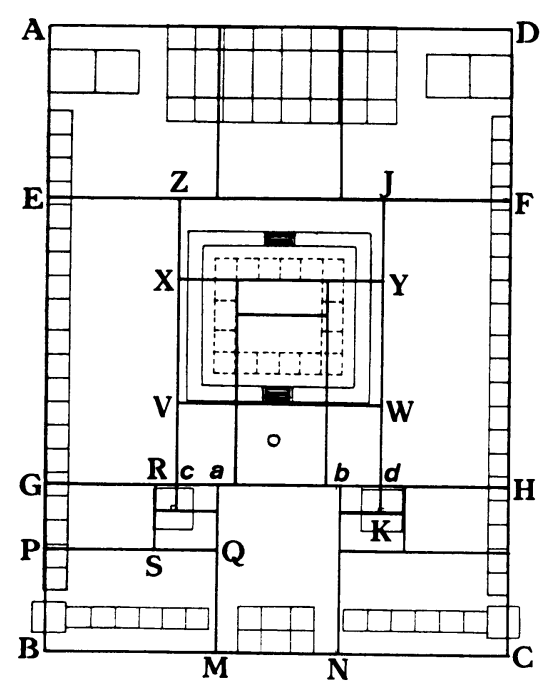

\section{図ー5 1.382矩形による千軍里寺址の 空間搆造分析}

象とし, 対数螺線 $(\sqrt{ } \phi)$ を利用して分析し た結果である。

礼仏空間の $\phi$ 矩形 (abcd)の空間尺度を $\phi$ 矩形を用いて分析して見ると, 先ず $\phi$ 矩形 (abcd)の長辺 $(b c)$ を半径として円弧を描い て長辺( $\mathrm{ad})$ と接する点を, $、 \phi$ 矩形の区分 点(e)とし $(a b f e=\sqrt{ } \phi)$, 次に $\sqrt{\phi}$ 矩形の対 角線(eb)を求め, それ之直角に交差する垂線 の延長線が長辺 $(\mathrm{ae})$ と接する点 $(\mathrm{g})$ を求める。

次に, (g)加直線を下ろし, 対角線 (eb) との交点(h)を定める。この過程を矩形の内 側に向けて反復すると矩形は無限に発展する。 このように求めた頂点を結んで曲線を描く之 対数螺線の $\sqrt{\phi}$ 矩形が得られる。

この方式で求めた線分 (on)は仏像座台の 上を通る。

即ち, 仏像座台の位置は、 $\phi$ 矩形線上と一 致する。

また，この(on)は仏国寺の中心一帯を囲 んでいる回廊の柱の間隔とも一致している。

このような対数螺線を利用した空間比例は 宋旼求の浮石寺の無量寿殿の分析結果（仏像 座台と仏像位置との関係を対数螺線を利用し た黄金矩形として提示している）と同じであ る。これは仏像座台の位置決定之仏国寺の伽 藍配置に適用された数理的比例との関連性を 表わすものと思われる。

このように，仏寺建築における対数螺線の 応用は，衆生の生之死は反復するものである という仏教の根本思想である因果律（輪廻思 想）との意味上の一致を物語るもので, イン ドで輪备説を象徵する造形として車輪, 即ち 同心円螺線を用いることとも関連性を持つ。 従って，仏像座台の上を通る仏国寺の対数
螺線は，このような教理的思想が伽藍の配固 に表現されたものと思料される。

(2) 千軍里寺址の空間構造分析事例

(i ) 1.382 矩形による空間構造分析

図一 5 は，慶州市千軍洞に位置する統一新 羅時代の千軍里寺址の復元図面("を対象に分 析した結果である。

これを見ると，短辺と長辺が1.382の比例 関係を持っている。本研究の対象地である仏 国寺と同時代に築造された千軍里寺址の空間 構造を分析した結果も, 重要造形物の位置と 1.382矩形の分割線が互いに一致しており, この矩形による空間分割の形態も同じく体系 的であり, 合理的な配冝形態であることが判っ た。このことは, 仏国寺と千軍里寺が築造さ れた統一新羅時代の比例体系の中心が 1.382 矩形であることを物語るものである。

\section{4. 結論}

伝統的な空間構成に導入された空間構成技 法を把握するために，仏国寺の創建背景及び 伽藍配置上に現われた外部空間の特性を分析 した結果は次の通りである。

1.382矩形の分析形態は, 独立した建物と 全体空間が組織的かつ体系的であった。即ち, 大雄殿の仏像座台の位置, 多宝, 釈迦両塔の 位置, それから紫霞門の位置など, 重要施設 物の位置と1.382矩形に空間を分割する分割 線が一直線上で合致しており，全体の空間構 成形態の場合も紫門から無説殿までの全体 の分割形態が大雄殿を中心に上下, 左右がそ れそれ対称を成し, 合理的かつ体系的な形態 を表わしている。

このような空間構成の対称技法は，空間に 強い安定感を与え, 寺刹建築の持つべき荘橄 かつ厳肃な宗教的な雾团気を醇し出すむので, このような意味上の空間表現が仏国寺の外部 空間に現われたるのと思われる。

1.382矩形の分析で見られる空間配置上の 統一された調和の概念は，華厳宗の全盛期に 築造された仏国寺造営の思想的な側面とも符 合するもので, 「一即多, 多即一」の概念を 根本原理とし，全ての個体の全体的な統一を 追求する華厳的な世界観が 1.382 矩形の整然 たる比例関係と共に仏国寺の伽監構造に相当 な影掣を与えたものと思われる。従って，仏 国寺の伽藍配置に適用された主なる比例体系 は1.382矩形であると推測することができる。

また1.382矩形は，仏国寺と同年代に築造 された千軍里寺址の外部空間です確認され， 1.382矩形がこの時代の比例体系の中心であっ たことが判った。

\section{参考文献}

1) 許東国 (1985)：建築デザイン, 明星出版 社, p.182-236 
2 ) 本光老 (1975) : 建築物の比例法則に関す る研究, 大韓建築学会集, Vol. 19, No.64, p.3-8

3 ) 米田美代治, 申栄勲訳(1974): 朝鮮上代 建築の研究, 東山文化社

4 ）姜友邦(1987): 石窟庵建築之造象に応用 された調和の門，美術資料，Vol.38

5 ) 南天祐 (1969) : 石窟庆に見る忘れられた 高度の新羅建築，診断学会

6 ) 宋旼求 (1987) : 韓国の古い造形の意味,
技文堂

7 ) 俞福模 外 (1988)：写真測量による仏国 寺の造形比に関する研究，韓国庭園学会

集, Vol.6,No.1, p.1-12

8）一然: 三国遺事，第 $3,4,5$ 巻

9) 姜裕文 (1937)：仏国寺古今創記跋, 慶北 仏教協会

10) 中村 元, 朴熙俊訳(1990)：仏教経典散 策, 民音社

11）文化財管理局(1987）：仏国寺発掘復元報
告青, p.25-27

12）俞 亮，俞吉溶訳(1987）：黄金分割，技 文堂, p.26-69

13）文明大(1987）: 石窟庵仏像彫刻の研究, 東国大学校大学院, 文学博士学位論文

14）鄭宙国(1987)：韓国建築様式論，一志社 p. $150-151$

15）江山正美(1984)：スケープテクチュア, 鹿島出版会, p.195-242

(1993. 4.9 受付, 1994.9.4 受理)

Summary: The purpose of this study is to develope the principle of mathematical beauty in traditional space-structure methods.

The method of this study is to analyze proportion-system in the outdoor space of Bulguk-sa Temple with its drawing. As a result of the analysis of the drawing 1.382 rectangle is found to be main-proportion system because each important positions such as Buddhistic statute seat, Sukga-tap and Jaha-mun with the starting point the outer pillar of corrider are in accord with the its proportion system. Also composition forms in whole space are expressed by rational and systematic space arrangement and each position of important buildings and whole space are compose of unified harmony.

\section{図書紹介}

\section{「よみがえるセントラルパーク 一管理と復元計画」 \\ 亀山 章監修・若生謙二訳 ソフトサイエンス社, 平成 6 年 11 月刊 A 4 版 166頁，8,755円}

庭園でも公園であ, その成立, 整備, 発展, 維持, 修復, 改修, 再生, 再建などのライフ サイクルがある。人間でいえば, 誕生から死 までの人生である。評者はこれを“生活史” 乙呼んで, 日比谷公園や横浜公園, 品川の御 殿山や浜離宮庭園などをケースに生活史的研 究を論文にしてきた。発表当初は, 生活史研 究などというるのは果して成立するのか？己 いう疑問を呈すひともいて苦労した。そんな 折, 「生活史研究って, ほんとに大事ですよ ねえ」と語りかけてくれたのが, 本書の訳者 若生謙二氏である。若生氏は, その頃から既 にセントラルパークの変遷に関心をもち, 幾 度か現地を訪ねていたようだ。

なお, 若生氏は現在, 大阪芸術大学助教授 である。

本書は，セントラルパークの公園長であっ たエリザベス・バーロー・ロジャーズ女史が 中心になってまとめたるの。テーマは，セン
トラルパークの「Rebuilding」(再建), 即 ちオルムステッド時代の状態への復元のため の基礎調査から管理計画までである。本書の 内容の全体像と意義については,訳者の監修 者である亀山章氏が前晴きで述べていること に尽きるが，凡そ以下の通りである。

1 ～ 3 章では, セントラルパークの歴史, 例えばオルムステッドの考え方や方法, アメ リカ民主主義との関係, その前史としてのイ ギリス風景式造園, その後の公園の衰退や変 化などについて述べている。

$4 \sim 8$ 章では, 公園全体の分析と提言につ いて述べている。公園利用の実態について, そこでの活動, 歩車道や乗馬道など利用動線 を。地形, 土壤, 排水については, 建設当初 の敷地の原形にさかのぼって検討され，その 後の環境圧による变化と解決策を提言してい る。植生と野生生物については, セントラル パークの公園景観の三つのタイプ一草地・疎 林・森林に分けて, 当初の構想, その後の変 化, 改善策について, 極めて詳細な調查やデー 夕をもとに論じ, 復元方策を提案している。

9 章は, 公園の管理についての分析と提言 である。セントラルパークの公園管理がいか なる組織と方針でなされてきたか, 具体的に

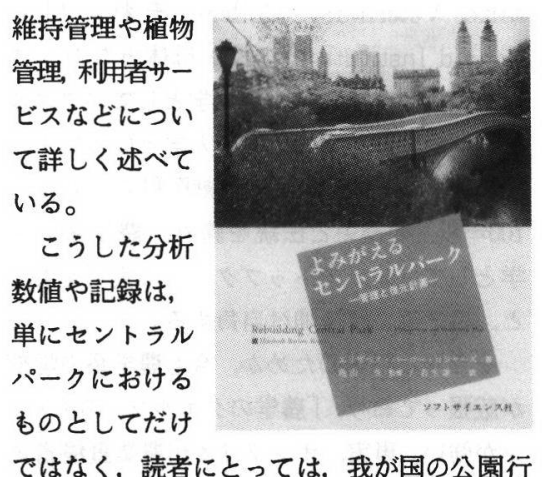

ではなく、読者にとっては, 我が国の公園行 政をいかに進めてゆくか，そのためにどのよ うな基礎調查や検討が必要なのかを, 具体的 に教えてくれる点で，大いに参考になろう。

10章と11章では，現在すでに進行中であり， 評者もその成果のすばらしさを眼のあたりに しているが, 復元事業の地区別詳細計画や処 方が示されている。

さらに新しくこの壮大なプロジェクトを推 進するためにつくられた「セントラルパーク 管理財団」の機能・役割・組織・スタッフ・ アッピールなどについてあ述べこの点むまた, 自治体の行政マンにとって大いに参考となる 内容である。

（進士五十八記） 